\title{
THE PARADOX OF INTEGRATION: European democracy and the debt crisis
}

\begin{abstract}
Europe is facing both a political crisis of democracy and legitimacy and an economic crisis of debt and competitiveness. These two seem to point in opposing directions, growing social unrest over the Europeanised mechanisms of economic adjustment, and increasing efforts at strengthening those same institutions that regulate the adjustment process. Recent analyses have suggested that this failure of democracy will prove decisive; legitimacy for crisis management efforts requires a re-democratisation of the European polity. Instead, drawing on an analysis of ordo- and neo-liberal traditions the paper explains how European integration was itself a response to the perceived threat of democratic demands at the domestic level. The body of the paper then traces the crisis through three phases, arguing that efforts by state managers reflect a deliberate attempt to depoliticize policymaking processes. Yet the selective intervention - to restore accumulation whilst withdrawing social spending - has only fuelled the politicisation of segments of European society. This threatens to test the limits of depoliticisation as a governing strategy.
\end{abstract}




\section{INTRODUCTION}

Europe is facing both a political crisis of democracy and legitimacy and an economic crisis of debt and competitiveness. These crises seem to point in two distinct directions: growing social unrest over the Europeanised mechanisms of economic adjustment, particularly in Greece; and increasing efforts at strengthening those same European institutions that regulate the adjustment process. The challenges that these "opposing" movements appear to raise for legitimate government are not inconsequential.

One important contribution has been offered by Brendan Simms (2012). Where the majority of commentators have been captivated by a combination of the political drama surrounding summits and compacts in EU high-level responses, and economic analyses of austerity measures or the anticipated Euro zone collapse, Simms proposes a roadmap to European deliverance. Through the emergence of a pan-European Party of the Democratic Union he suggests that a mighty, democratic union could be forged in the crucible of the current crises. For him, stronger centralized institutions are a necessary condition of crisis resolution and economic governance, though he recognizes that this resolution is an insufficient condition for European recovery unless it is founded on the acceptance of the European demos, providing the requisite democratic legitimacy. He thus calls for a democratisation of the European polity, secured through a new movement of the people.

His contribution is also important because it resonates with much of the European studies literature on the "democratic deficit" in the European Union. Here too the suggestion is that a rebalancing of institutional relations could serve to re-democratize the Union (Schmidt 2012). In response, the argument of this article is that European integration has itself been inversely correlated with the challenges of democratic participation at the domestic level. Put rather more bluntly, excessive democratic demands were blamed for the prolonged post-war crises of accumulation at the domestic level; thus the "democratic deficit" was no unfortunate side-effect, but integral to a European project intended to replace political discretion with supranational, depoliticised policymaking. This move was predicated on a fundamental restructuring of post-war class compromises in favour of capital, and has only been reinvigorated by the current crisis.

Together, this suggests that "legitimacy" will not be achieved through democratic means, but through depoliticisation, or the attempt to place at one remove the political character of economic decision-making (Burnham 2001) - as the governing strategy that has characterised integration. I begin by exploring the ordo- and neo-liberal conceptions of the democracy question in Europe to support this claim. The main body of the article focuses however, on a close reading of key developments in the evolving Euro zone crisis. It argues that, in keeping with earlier integration efforts domestic and European-level state managers have again pursued depoliticisation as a means to restructure social 
relations, whilst reducing openings for democratic demands to influence market mechanisms and the political process.

The article tracks the evolution of this political strategy through three phases in the European crisis. It contends however, that the challenges state managers face in promoting a coherent strategy is complicated by the increased politicisation of segments of European society. In the conclusion I therefore address the threat - in the absence of a new democratic settlement - of the Euro zone crisis developing into a political crisis of the state (Burnham 2011 , see also Macartney 2011 ).

\section{EUROPE'S “TWIN” CRISES}

Since late 2009 we have faced daily the barrage of discussions of Greek default, downgraded sovereign credit ratings, and landmark European Union summits. At face value, the most pressing issue appears to be that of the Euro zone debt crisis, coupled with renewed efforts to promote structural reform in the name of increased competitiveness. In the background however, forms of heightened resistance - initially targeting profligate bankers and the austerity doctrine, yet more recently taking the form of an open debate on the future of Europe, finance, and indeed capitalism - have gained momentum. The awareness that democracy and transparency have been foremost casualties of the crisis management process has only highlighted the widening disconnect between high-level politics emanating from Brussels and the demands of the European masses (Persson 2012).

Simms' argument, as I understand it, is that the European Union is on the edge of oblivion. Faced with the collapse of the Euro zone, sudden debt default and rising xenophobia across the Union, something radical must be done (Simms 2012: 54). He bravely suggests a 'closer and more perfect union', by which he means the 'immediate creation of a fiscal and military union of the continent', complete with a Union parliament, the federalizing of state debt, and a single European army (ibid.: 60). To support this he draws on an extensive knowledge of successful (and unsuccessful) unions (ibid.: 50). Finally, he argues that the means to achieve this 'mighty Union' is through the formation of a pan-European 'Party of the Democratic Union', expressing the democratic will of the citizens and involving the overthrow of national forms of sovereignty (ibid.: 62).

In his view, a large part of the problem derives from the clumsy division of powers between national and European authorities, with the EU lacking the centralized institutional capacity to decisively subordinate persistent national identities and interests (ibid.: 60-62). This explains the renewed shift towards 'economic government' as the perceived solution advanced by Franco-German elites.' Yet Simms quickly dismisses this as insufficient without the accompanying 'direct democratic participation of the citizens of 
Europe' (ibid.: 60). As he points out, since they are the ones being forced to advance large sums of money and bear the brunt of structural reforms they must 'buy-in' to the new settlement for it to achieve credibility (ibid.: 49). This it would seem is the crux of his argument, for Simms contends that the sheer extent of the political and economic costs will prove to be unbearable, with efforts of EU elites failing and default and break-up the result unless pan-European consent can be secured.

Simms' contribution is important, not simply for the fact that he highlights the alarming absence of mass engagement with Euro zone crisis management efforts, but because he also provides a much needed blueprint for 'positive' agency where other accounts of the crisis only bemoan the lack of ideological and political alternatives to further neoliberal austerity. Moreover, his assessment of the challenges facing Europe also resonates with the longstanding debate on the so-called "democratic deficit" in European Union studies. These accounts have noted, inter alia, the relatively weak legislative powers of the European Parliament, in spite of numerous reforms, vis-à-vis the executive powers of the Council and Commission (Andersen and Burns 1996, Raunio 1999). Likewise, it has been suggested that the European electorate has little or no input into the selection of parties and personalities at the European level or the direction of the EU policy agenda, in spite of the growing power of the European parliament (Marks et al. 2002). Further, and most importantly for the argument presented here, there is evidence of 'policy drift' whereby 'the EU adopts policies that are not supported by a majority of citizens in many or even most Member States' (Follesdal \& Hix 2006: 537). In particular, governments are able to pursue policies at the European level which are constrained by social democratic-style compromises at the national level, meaning that the pursuit of neoliberal regional regulation and monetarist policy tend to be to the right of the domestic policy status quo (ibid.: 537-538). These accounts have also emphasized the nascent European technocracy as the corollary of the hollowing out of the national state, both processes driven by conditions of increased interdependence and the inability of elected officials to grasp the complexities of globalized policymaking (Rhodes 1994). This, we are told, is a 'governance by rules' that typifies the division of labour between weakened national authorities and only semi-autonomous European-level bodies (Heipertz \& Verdun 2010: 203-204).

Located within this paradigm more recent accounts have thus argued for a redemocratisation of the European Union. The problem, it appears, is that the balance of power between European institutions has become further unsettled through the course of the crisis: decision-making processes have increasingly combined 'excessive intergovernmentalism with technocracy'; the European Council has monopolised decisionmaking at the expense of the European Parliament (EP); and the European Commission has lost its role as initiator, being demoted to that of a mere secretariat (Schmidt 2012). The exigencies of crisis management have (momentarily?) prompted policymakers to sidestep time-consuming democratic politics; exacerbating the sense of detachment between high- 
level processes and the European electorate at precisely the time when European policies are perceived to have an ever greater impact on everyday social existence. Thus 'what the Euro zone needs now is not only new policies and better leadership in the Council but also a more involved EP and a more political Commission President, legitimated via parliamentary election' (ibid.). The parallels with Simms are obvious.

In contrast, I will suggest that the debt and democracy crises are part of a dynamic and contradictory process of class struggle, whereby the direction of one - supranationalised, opaque governance - derives, at least in part, from the direction of the other - heightened social unrest (see Ollman 1998: 339-340). To explain this I begin with the work of ordoand neo-liberal thinkers on the relationship between the free market and democracy. I will argue that these assumptions were integral both to the framing of the European project, and contemporary responses to the European crises.

\section{THE FREE MARKET \& DEMOCRACY}

In essence, the challenge posed by democratic demands is a familiar one. This is because there has long been - across the advanced economies - a growing disquiet over the 'economic consequences of democracy' (Brittan 1976). Put simply, 'excessive expectations' on the part of electorates were fuelled by the 'democratic aspects of the system', whereby social demands were seen to have overstretched the welfare state (ibid.: 97). The post-war settlement had allowed for full employment and welfare because of the booming economy, and thus signalled a 'conscious acceptance on the part of national governments of [the demands of] mass society and mass democracy' (Bonefeld 2002: 122). Yet the end of the post-war boom revealed the merely formal involvement of the dependent masses, integrated into the political economy of capital only to contain their political aspirations. Thus the post-war welfare state was embedded in a European structure of market competition (Moss 2000).

As these crises of accumulation emerged two intellectual traditions were pivotal to attempts to understand causation. One was closely associated with the work of Milton Friedman, Friedrich Hayek and the Mont Pelerin Society, and is commonly characterized as neo-liberalism. The other emerged from the Freiburg School, was closely associated with the work of Walter Eucken, Franz Böhm, Alexander Rüstow, Wilhelm Röpke and Alfred Müller-Armack and became known as ordo-liberalism.

For Hayek and Friedman, the aim was to free the economy from political interference, depoliticising economic relations such that the market could self-regulate (Hayek 1949). Thus 'active public economic policy [was, in their view] either redundant or, more likely, perverse' (Best 2005: 92). Not only governmental intrusion but strong trade unions too were to be avoided. Instead, the relationship between the money supply and labour 
productivity would be strengthened through the deregulation and flexibilisation of the labour market, accompanied by the shift from welfare to workfare. Thus, in response to what they perceived as the inflationary consequences of Keynesianism, Hayek in particular advocated the depoliticisation of economic policymaking from political - that is discretionary - intervention in the short-term interests of the working classes.

For Müller-Armack and the ordo-liberals, regulative laws and institutions were needed in order - not to interfere with the market process - but to sustain it (Müller-Armack 1947: 95). This meant that the ordo-liberals favoured a strong state - not of the dirigiste type but as the precondition for the free market, since the mass of society lacked the 'moral fabric' to absorb economic adjustments, preferring short termist policy responses that favoured employment and welfare (Röpke 2009: 52; 1942: 246-247). An "extrademocratic" body would thereby govern in the name of technical efficiency and expertise, without interference from mass demands. Given that the true interest of the worker lay in continued accumulation, social security and employment, the threat that democracy here posed to liberalism was not insignificant (Müller-Armack 1979: 146-147). The movement of the free price mechanism, they concluded, had the capacity to regulate between multifarious individual preferences, except that its participants 'rebel against that movement' (Böhm 1937: 11, Bonefeld 2012: 5). This could occur equally through entrepreneurs opposing the pressures of competitive adjustment as it could through the self-destructive demands for welfare on the part of workers. Thus, for the ordo-liberals the solution was the depoliticisation of society to tackle the subordination of the political to mass democratic demands.

Yet it was Hayek whose vision of a federal interstate system in Europe that was remarkably prescient. He contended that a supranational political architecture would foster competitiveness, and the depoliticization of economic relations, whilst - of course allowing for the free movement of capital, labour and goods (Hayek 1939: 255-268). Since national governments, committed as they claim to be to the objective of price stability, necessarily retain a degree of discretion this, in his view, makes them liable to exploit it to gain electoral popularity by granting concessions to the dependent masses. Giving monetary policy to an institution that is not subject to political influence' would thus enhance its credibility (Padoa-Schioppa, 1994: 188). Put differently, and here there was a certain confluence with the work of - in particular - Müller-Armack, a domestic politics of austerity could be anchored in a supranational regime (1971). Thus supranationalism, and in particular, the primacy of the rule of law and an independent central bank, were 'endorsed as a way of keeping the masses away from the centre of decision making' (emphasis added Bonefeld 2002: 130).

Hence Europe was necessarily an elite-driven project (Anderson 1997: 62). For centre-left parties, integration was a 'way of defending the market economy against Communism while retaining a humanitarian internationalist identity' (Moss 2000: 251). Yet according to 6) P a g e 
Moss, this masked the reality that the single market and monetary union reflected tightened capitalist domination (ibid.: 252). For centre-right parties this reality was more apparent, as Europe provided the means to impose market disciplines on industry, to increase labour productivity and competitiveness. As De Gaulle (1971: 143) surmised, 'international competition...offered a lever to stimulate our business sector' that diverted the focus away from French policymakers. Whilst for capitalists in industry, finance and agriculture, the single market operating under a tight monetary policy was a means to undermine national social regulations and promote wage restraint (Bieler 2006: 12-13). Indeed, 'why should a 'domestic' bourgeoisie not wish that 'its' working class is made to work harder and for declining wages, and to achieve this in a way which makes it appear as if the bourgeoisie is not responsible for the burden placed on labour?' (Bonefeld 1998: 58).

As the 1990s unfolded it was all the more apparent that the currency union was informed by such thinking. Michael Emerson explained that 'a stable and credible monetary regime requires an independent central bank with the statutory mandate to guarantee price stability... [since] in democratic societies elected officials are in general free to determine economic policy at their discretion' making it 'very difficult for political bodies to acquire enough credibility' (1992: 87, 97). Moreover, for Tommaso Padoa-Schioppa, this collective decision-making mechanism thereby increasingly replaced national hegemony over monetary policy - and hence national centres as focal points of social and political struggle - with community, centralized institutions (1994). Economic and Monetary Union (EMU) institutionally reinforced the separation of political from economic considerations, on the premise that the management of the European economy was too sensitive and significant an issue to be disrupted by political expediency; it insulated 'key economic agents, especially [the European] Central Bank, from interference by elected politicians' (Gill 1994: 168, see also Shields 2008 for a similar critique of the EBRD).

This was because the distributive implications of the separation between monetary policy and price stability - under the auspices of EU-level institutions and the European Central Bank - and welfare and labour market policy - in the hands of member state governments - had long been a concern for core Franco-German political classes (Gros \& Thygesen 1992: 35).ii The rise in supranational economic policymaking was intended to remove from national elites both the freedom and responsibility for a 'distasteful' politics of austerity; such initiatives were now imposed from above by European-level institutions, empowering the national government to argue their own impotency in the face of mounting pressure from their electorate.

The defining feature of European integration is its attempt to construct a free market mechanism that is progressively more insulated from working class aspirations (Bonefeld 2005: 93). The means to achieve this is via the commitment to and construction of Europeanised mechanisms of economic adjustment and institutions that back this 
commitment up, removing the impetus for adjustment from national ruling classes, whilst placing the burden of adjustment firmly on domestic working classes.

\section{An incomplete project}

In reality however, the European project was only partially complete as the global financial crisis began to unfold in 2007 . The very fact that the Lisbon agenda had entered a second phase in 2005 was evidence, for example, of the growing awareness that the challenges of structural reform and competitiveness had not been met. Beginning with the Kok Report (2004: 7) the EU had acknowledged that 'the European Union and its Members States have clearly themselves contributed to slow progress by failing to act on much of the Lisbon strategy with sufficient urgency'. As a result national reform programmes were introduced, whereby plans to address poor productivity, rigid product and labour markets, bureaucratic barriers to public and private investment and innovation, and budgetary discipline, were shaped at the national level and subsequently submitted to the Commission for review. Significantly however, by January 2006, as the Commission formulated its first Annual Progress Report on Growth and Jobs, progress had been limited (Commission 2006a: 4-5). From the perspective of European elites this was 'Time to move up a gear' (Council 2006).

Moreover, EU institutions were not alone in their concerns over remaining resistance to neoliberal structural reforms and the apparent weakness of member state governments in addressing these 'productivity gaps'. In its 2006 report on Economic Policy Reforms: Going for Growth, the OECD noted that the EU was lagging approximately 30 per cent behind US GDP per capita. As a result, reform of unemployment benefits, work incentives, and the reduction of labour costs, in Germany, Belgium, and France were viewed favourably; whilst the lack of such reform of benefits systems in Greece, Luxembourg, the Slovak Republic and Spain was criticized (2006: 11-17). Similarly, in its Article IV comments (2006) the IMF pointed to the need for further fiscal consolidation, and reform of overly generous welfare states and labour market rigidities, with a particularly damning prognosis for peripheral countries.

In particular, European integration had paradoxically weakened the pressures for neoliberal (pro-competitive) restructuring for certain countries, thereby exacerbating the trend of a two-tiered Europe: with export-led growth in the core and mounting deficits and productivity imbalances in the periphery. For instance, whilst Germany, France, Holland and Finland maintained an average fiscal deficit of only 1 per cent for the period 2004-06, Italy, Spain, Greece and Portugal had a mean deficit of 4.4 per cent. iii Moreover, these same periphery countries witnessed a significant decline in their competitive position vis-à-vis the rest of the Euro area (Commission 2008: 58). In effect, Euro entry had led these countries to accumulate high levels of private and/or public debt and run 
large current account deficits (Darvas et al. 2011: 2). These same 'cohesion countries'iv (Greece, Spain, Ireland, and Portugal in particular), precisely because of the adoption of the Euro, which prompted a downward convergence in interest rates and risk premia, had gained increased access to external bank lending since the mid-1990s. This, coupled inter alia with above average inflation rates (leading to lower real interest rates), demographic changes, and reforms within mortgage markets themselves, had further eased credit conditions (Commission 2006a: 28). This meant that that their relatively strong performance on paper had been fuelled by investment booms, spurred by capital inflows attracted by comparatively high rates of return, with the single currency and the integration of financial markets acting as a catalyst (Commission 2008: 21). The point, for our purposes here, is that the imperatives of austerity and structural reform - that were central to economic and monetary integration - were diluted by, inter alia, cheap credit and housing equity.

Put differently, existing class compromises that comprised part of domestic democratic settlements were less exposed to the pressures of international competition than the designers of the European project had intended. Marx recognised this, highlighting that if labour engages in the same project of prosperity as capital, albeit underpinned by credit, capital's ability to exercise an ever-tighter command over the working classes is lost. As he has it (1990 [1867]: 765) 'those that get their living by their daily labour ... have nothing to stir them up to be serviceable but their wants which it is prudence to relieve, but folly to cure. The only thing then that can render the labouring man industrious, is a moderate quantity of money, for as too little will, according as his temper is, either dispirit or make him desperate, so too much will make him insolent and lazy' . Expansion of credit thereby inadvertently undermines the very conditions necessary to promote neoliberal structural reform (Macartney 2009: 114).

In what follows, I will show how the crisis provided - at least initially - conditions apposite to renewed structural reform and strengthened mechanisms of adjustment; or the recomposition of class relations and tightened market-based constraints over labour and money. I trace the crisis through three phases: the first, addressing the need for neoliberal structural reform; the second, with the emergent debt crisis and the (re)turn towards depoliticisation as a governing strategy; and the third, where the limitations of depoliticisation in the face of growing (politicised) resistance become more apparent.

\section{PHASE 1: FROM RESTRUCTURING TO DEBT CRISIS}

This centre section of the article therefore traces out the European-level responses since 2007. Indeed, though the early stages to the crisis were manifested as banking collapses, they served to generate the requisite hysteria that state managers subsequently channelled into the reform process (Jessop 2012). In particular, the $€ 73.2$ bn write-downs 
of Euro area large and complex banking groups (LCBGs) by November 2008, and the drop of almost $€ 200 \mathrm{bn}$ in market capitalization gave rise to an unprecedented degree of political coordination (ECB 2008: 11-12, ECOFIN 2008). The response was part of a decisive move by national governments, and came in the form of a 'Declaration of Concerted European Action Plan' at an emergency summit. The decision to avoid bank failures was pivotal here, with the Lehman episode effectively constituting a moment of intense policy-learning for the state. Given the 'exceptional circumstances', national leaders and European elites (henceforth state managers) appeared to suspend both democratic discussion of the end-costs of the bailouts, in a manner not unreminiscent of the emergency powers invoked during times of war.

Beyond the immediate bailouts and (short-term) counter-cyclical spending however, the European Economic Recovery Plan (EERP) also captured Lisbon II's emphasis on addressing "necessary" structural reforms. Here the Commission emphasized the disparity between wage-setting mechanisms and productivity in certain countries, and the lack of flexibility of labour market arrangements. An increase in competition, an attractive economic environment for international capital, and deepening of the rule of market discipline over the labour force; these formed an overarching vision, whilst the strategic targeting of spaces and enclaves previously under-exposed to these imperatives became the next priority after stabilization. The point was that state managers quickly recognized the potential to use the crisis to target many of the remaining post-war measures that had benefited the working classes (Burnham 2011: 506). Thus whilst Colin Hay and Daniel Wincott are correct in emphasizing that the welfare state need not necessarily be the primary casualty of the global financial crisis, it matters not: the rebalancing of class forces in favour of capital that has taken place since 2007 has deliberately attacked the Western European public sector, health, pensions, and housing benefits as symptomatic of earlier political susceptibility to (democratic) working class demands. This is the polarising effect of crises (Moss 2000: 253).

In turn, this agenda was then enshrined in the conditionality of Community financial assistance and the Globalization Adjustment Fund (EC 2009). Furthermore the Commission began the process of assessing the Stability and Convergence Programmes of the eleven countries with budget deficits (at that time) within the 3 per cent limits of the Stability and Growth Pact, and then another group of six countries which had breached the 3 per cent reference value (Commission 2009a). A subsequent Commission Communication then marked the renewal of 'action....which targets efforts on the long-term objective of building a competitive and sustainable EU economy, as set out in the Lisbon strategy for Growth and Jobs' (Commission 2009b: 2). Yet it was the specific targeting of budget deficits that rose, as we now know, to the fore. As Hugo Radice (2011) subsequently emphasized, though there are no objective limits to state spending, two underlying reasons motivated the shift towards fiscal consolidation: one was that international capital 
had long enforced a politics of austerity through European monetary policy, and was not about to lose this ground; the second related factor however, was that for EU-level and core member state state managers, the very legitimacy of the monetary union was called into question. As the electorate was increasingly aware, if 'Keynesian' style deficitspending could be invoked by national governments to rescue the banking sector, why accept further wage moderation and reduced spending in the public interest? In essence, short-term fiscal stimuli and banking bailouts were fuelling a repoliticisation that ran counter to the trend of technocratic politics at the heart of the Euro zone project. From the outset the management of the debt crisis was deeply infused with the containment of democratic demands.

Indeed this reality was not lost on the EU institutions. At the Brussels Economic Forum 1415 May 2009 for example, European Commissioner Joaquín Almunia captured this sentiment, stating: 'At this juncture, immediate crisis response is our first priority. And yet, in our efforts to manage current challenges, we must take a longer-term perspective. Deep crises...bring powerful lessons for economic governance' (2009, emphasis added). This was becoming a question of balancing the timing and scale of the withdrawal of budgetary support, consolidating budgets, and introducing structural reforms to replace the supposedly artificial 'propping-up' effect of state aid, whilst addressing productivity gaps. Beyond these economic considerations however, this involved a very real political calculation of responding to the demands of capital (withdrawal and reform) without further exacerbating the simmering discontent of disaffected social groups. Of course, the political management of this struggle has proven to be a relatively elusive task, resulting in the second phase - in a more depoliticized statecraft (Commission 2009c: iii, ECOFIN 2009a: 6; 2009b).

\section{PHASE TWO: FROM DEBT TO DEPOLITICISATION}

Renewed depoliticisation became most urgent from late 2009-early 2010. On 14 October 2009 the Commission had issued its Communication on the Long-Term Sustainability of Public Finances, with the following ECOFIN meeting (19-20 October) indicating that, dependent on further signs of economic recovery, fiscal consolidation should begin in all member states by 2011 at the latest (Commission 2009d, ECOFIN 2009a). Yet by 9 December the EU's strategy was seemingly already under siege as financial markets and ratings agencies expressed concerns over the sustainability of Greece's public finances (Reuters 2009). Here most accounts of the sovereign debt crisis implicitly reinforce the view of member state governments at the mercy of international bond markets and ratings agencies. Instead, the "sword of Damocles" hanging over national governments again crystallised resolve, whilst providing the ideal rationalization for both austerity and supranationalism. 
What was perhaps most striking however, was the more coercive and interventionist approach that the EU institutions - motivated in large part by German zeal - began to adopt in promoting this agenda (see also Heipertz \& Verdun 2010). Greece provided the ideal testing ground. As the Greek government submitted its Stability Programme for 2010-2013 to the European Commission on 15 January, the plan was to reduce the budget deficit to 8.7 per cent of GDP in 2010 and thereafter to 5.6 per cent in $2011,2.8$ per cent in 2012 and 2 per cent in 2013 . Already the programme was radical in its scope: it proposed the elimination of tax exemptions; the rise of excise duties on tobacco and alcohol; as well as measures to fight tax evasion. Beyond that, the government planned to reduce expenditure by cutting public servant allowances; freezing recruitment in 2010 and reducing the number of civil servants recruited to replace future retirees by 80 per cent; freezing all budgetary appropriations per government ministry by 10 per cent; and adopting nominal cuts in public consumption and operational expenditure (Commission 2010a). The programme also outlined a number of structural reforms aimed at improving the budgetary framework and the efficiency of public spending, enhancing investment and improving the functioning of labour and product markets. It seemed that past failures by the state in being over-responsive to the demands of the electorate were being redressed.

Under Article 121(4) of the Union Treaty however, the Commission recommended to the European Council that an even more comprehensive structural reform package be agreed, in order to maintain the 'consistency and functioning of the monetary union itself', and urged Greece to cut its overall wage bill.v This was also supplemented by a recommendation under Article 126(9) giving notice of the need for immediate deficit reduction measures and launching an 'infringement procedure' against Greek authorities for their failure to report reliable budgetary statistics (Commission 2010b). The significance of this act was monumental: this was the first time that the budgetary and economic surveillance instruments foreseen in the Treaty were used 'simultaneously and in an integrated way'. The recommendations were subsequently endorsed by the ECOFIN Council on 15-16 February, in collaboration with experts from the ECB and IMF, in what was an 'impossibly stringent and intrusive' budgetary adjustment programme (Schelkle 2010: 9, ECOFIN 2010a). This next phase of the crisis was widening the political opening for EU institutions to expand and exercise their authority, beginning by deploying existing but previously unused policy instruments.

Even as Greece introduced the next round of cuts then, the downward debt spiral was visibly undermining the stated rationale for austerity, meaning that only the most hardened observers could cling to the claim that austerity was primarily a growth-inducing strategy. In the dominant rhetoric, austerity was intended to reassure international markets that 'high and unsustainable' deficits (and, by extension, prolonged public involvement) would be tackled; in so doing the costs of borrowing would fall as private investment and output responded favourably. Yet, as Greek PM Papandreou addressed the 
European Parliament's Special Committee on the Economic, Political and Social Crisis (18 March) it was becoming apparent to even the most agnostic onlookers that the austerityfor-growth plan wasn't working (Parliament 2010). Instead, austerity provided a golden opportunity to address heavily entrenched class compromises and reconfigure "dysfunctional" institutions, just as the repeated failure to return to growth galvanized political resolve to adopt ever more extreme measures.vi

This was apparent when the European Council met on 25-26 March 2010 to establish an emergency mechanism comprised of bilateral loans and IMF funding. The second, less well publicised, impact of the Council meeting however, was to begin the formal process of exploring how to strengthen the legal framework surrounding the surveillance of economic and budgetary risks (Council 2010: 2). As Papandreou had put it only a week earlier, these were precisely the 'institutions which [were] missing in this project' (Parliament 2010). At a European Policy Centre conference (1 5 April 2010) on Reinforcing Economic Governance, European Commissioner Olli Rehn therefore noted that the crisis had revealed institutional and structural inadequacies: 'Peer pressure has lacked teeth to ensure timely and effective action. Member states did not use the good times to reduce the public debt. Macroeconomic imbalances were neglected' (Rehn 2010a).

The philosophy underpinning this claim should by now be apparent: national governments had failed to be sufficiently stringent in exercising wage moderation and curbing redistributive policies. The liberal state - as enforcer of market discipline - had succumbed to the democratic state. The result had been high public debt; the solution was stronger technocratic oversight of national economic management, in part compelling state action, in part diluting state culpability. The shift was from a discretionary to a more formalized, rule-based statecraft; and from solely a monetary emphasis, to a strengthened economic pillar, overseeing - inter alia - fiscal policy. In this regard there had been 'no political appetite for action...until today' (Rehn 2010a).vii

As a result, the Commission - in its (new) role as secretariat to the Council - proposed to reinforce the preventive and corrective arms of the SGP. In their view the Excessive Deficit Procedure of the Pact required additional penalties to be imposed on member states flouting the terms. Similarly, they indicated the need to go beyond simply monitoring budgets, by extending surveillance of macroeconomic imbalances and competitiveness divergences (Commission 2010c). Against the background of a nascent 'Europe 2020' vision these surveillance mechanisms were pivotal. Where Europe 2020 aimed to increase both the pace and intensity of structural reforms, there was a clear awareness of the forces of resistance that this would inevitably provoke (ECB 2010: 5-7, Commission 2010d: 2, 48-49). So the Commission set out a plan for more detailed instruments, comprising a preventive and a corrective disciplinary arm, again distancing domestic state managers from unpopular policies. The preventive arm would give the Commission powers to assess macro-structural weaknesses, deteriorating competitiveness and emerging macro-

13 | P a g e 
economic imbalances; in particularly serious cases, the Commission would recommend placing the member state in an 'excessive imbalances position'. This would then trigger the 'corrective arm', whereby the respective member state would be subject to stricter surveillance, with policy recommendations then issued by the Council and the requirement to report to the ECOFIN and Eurogroup on progress in implementing the necessary reforms. Finally, the Commission proposed a European Semester, so that 'complementarity of national economic policy plans [would be] ensured at the European level through policy guidance before final decisions on the budget for the following year are taken in member states' (Commission 2010c: 11). This would enable a 'horizontal' assessment of national fiscal policy, in a way that sidestepped the more politically volatile idea of a full fiscal union. As the Task Force subsequently concluded, this was the 'biggest reform of the Economic and Monetary Union since the Euro was created' (van Rompuy 2010). The point was that the horizontal integration and the vertical, increasingly hierarchical yet formalized distribution of powers were again - in large part - responses to the underlying problems of excessive popular demands and the residual discretionary authority of state actors.

\section{PHASE THREE: FROM DEPOLITICISATION TO RESISTANCE}

Both the new (supranationalized) legal-institutional architecture and the opacity of the increasingly intergovernmentalized policy process, coupled with the austerity doctrine itself, predictably exacerbated social unrest. In effect, the challenge that this third phase has posed to state managers is that of selective intervention - to renew accumulation - on the one hand, whilst containing an increasingly politicised series of resistance movements, on the other. As Peter Burnham (2011: 499) noted, the 'tightrope state managers have to walk in this situation is how to intervene in crucial areas to restore profitable accumulation (recapitalization, nationalization, quantitative easing) whilst simultaneously withstanding demands to intervene in other areas to the advantage of particular groups (manufacturing industry, low paid workers, the unemployed)'.

Initially, rising civil protests seemed only to erode ruling class intransigence to a further rescaling of powers, thereby forging a new degree of consensus between Franco-German and European-level state managers. This was particularly the case for Germany when, on 2 February 2011 , Merkel and Sarkozy reached an agreement on proposals to strengthen policy coordination and fiscal discipline. The point to note was that Germany now agreed to give new powers to the Euro area rescue fund, in exchange for fiscal discipline commitments by other Euro members, in what was flagged as a reversal of Chancellor Merkel's position of 2010 (The Guardian 2011 a). This 'pact for competitiveness' basically meant that other members would introduce constitutional reforms similar to the German 'golden rule' of balancing the budget (Reuters 2011 a). As Czech President Vaclav Klaus 
noted, this constituted 'a radical reduction of the sovereignty of other EU countries' (ibid.). Opposition was such that the proposed reforms were eventually revised, but the resulting 'Pact for the Euro' nonetheless took further steps to oversee national economic policy. Where the earlier reform of the Stability and Growth Pact had increased supranational surveillance and enforcement, the Pact for the Euro focused primarily on enhancing multilateral coordination of (nationally implemented) economic policies, including certain areas of tax policy (Euro Area Heads of State 2011 , Council 2011 ).

The longevity of the sovereign debt crisis was thus providing state managers with both motivation and legitimation for more radical reform, indirectly ignoring democratic criticism in the interest of restoring stability and (neoliberal) growth (Eurogroup \& ECOFIN 2011 ). This came to the fore at the European Council summit 8-9 December 2011, where a new Fiscal Compact for the Euro area countries was under negotiation; this would mean a requirement for national budgets to be in balance or in surplus and for this to be enshrined in national legal systems. The corollary of this was that member states in deficit would have to submit to the Commission and the Council their plans for structural reforms to reduce the deficit. This was a substantive 'move towards a stronger economic union', meaning that the institutional and legislative apparatuses to enforce the principles of sound finance already residing at the heart of Economic and Monetary Union would be emboldened (Council $2011 \mathrm{~b}$ ). It was yet another step that reinforced the prevailing wisdom that national governments had failed in their task as enforcers of market discipline. Instead this responsibility would now increasingly pass to a higher level.

The prolonged financial speculation of international markets had a second corollary effect though. Indirectly targeted at recomposing class relations and reducing state support in areas of social spending, financial markets became progressively more agitated - through 2011 - by the continued inability of state managers to act decisively. Yet this inability derived in large part from an accountability to an increasingly active and enraged electorate. State managers spoke for example, of the 'remorseless logic', driving towards greater political and economic integration (Osborne 2011). Yet the heightened political engagement of European working classes threatened to destabilize the entire process. This realization lead one informed observer to suggest 'only a full-blown crisis [would] convince... electorates of just how severe their predicament [was]' (Hamilton 2011). Indeed, the multifarious and geographically diverse protests that had emerged from early 2010 , had prompted another commentator to contend that the 2010-11 European 'winter of discontent' could to be just 'the start of the greatest demonstration of public unrest seen on the continent since the revolutionary fervour of 1968' (O'Grady 2010).

The politicized resistance came in three overlapping skeins: in its earliest form protests targeted the financial community, and continued with the more recent "Occupy" movement. For the purposes of this paper though I am more concerned with the latter two strands: one focused specifically on governmental austerity policy; the other targeting the lack of 15 | P a g e 
democratic transparency and participation in recent policies. Greece was of course, the epicentre as the test-case for the austerity doctrine. As a direct result of the Commission's revisions to the Stability Programme for 2010-2013, the Greek public came out in protest, with customs and tax officials holding a one-day strike on 4 February 2010 followed by a general strike on 24 February (Guardian 2010a). Greek Prime Minister Papandreou perfectly captured the emergent political consensus, shared by EU and Greek state managers, on the required course of action: he suggested that 'Our duty today is to forget about the political cost and think only about the survival of our country. Past policies make it necessary to proceed to brutal changes and reduce accumulated privileges' (Telegraph 2010). Yet the Greek public seemed to disagree, with over two million workers taking to the streets early in the spring.

Moreover Greece was not alone. Already by March rallies and general strikes were taking place across the continent. In Spain protests against raising the retirement age gathered in Madrid, Barcelona, Valencia; in France industrial action at airports and oil plants over the proposed closure of refineries; in Italy at car production manufacturers; and in Portugal over planned wage freezes. Indeed by September, it seemed that the relatively individualized national protests might be giving way to a fledgling pan-European movement as the European Trade Union Confederation (ETUC) organized a coordinated European Day of Action. The demonstrations in Brussels and multiple capital cities, under the slogan "No to Austerity: priority for jobs and growth", were an attempt to 'send a message to leaders as they contemplated new cuts in wages, pensions and employment benefits to balance their budgets' (ETUC 2010). By November 100,000 workers gathered in Ireland alone, in one of the largest demonstrations in the country's history. In particular, the protests were targeted at what they considered to be the incomprehensibly severe budget cuts required by the troika's $€ 85$ bn rescue package (Guardian 2010). Then in December similar scenes were witnessed in the Czech Republic - with its biggest strike in more than two decades - whilst other protestors formed a human chain around the Commission building in Brussels ahead of the Euro summit to agree the permanent emergency fund. The goal was to symbolize the belt-tightening that they feared would 'destroy wages and welfare systems' (Spiegel 2010).

Whilst the focus shifted to the Arab Spring as 2011 began, the proposed Competitiveness and/or Euro Plus Pacts of March 2011 again triggered unrest. Indeed, the measures provided a particularly clear focal point for workers. As European finance ministers met in Ljubljana, Slovenia on $5^{\text {th }}$ April, Europe's trade unions organised to demand increased pay, in opposition to the programme of sustained wage moderation. Meanwhile, as French unions rallied against wage restraint and pensions reform (19 April), Bernard Thibault of the CGT argued that the Euro Pact 'had made labour costs the mechanism for exiting the crisis'; instead emphasising that 'the systems of social protection are not the origin of the international financial crisis - it is totally illusory to think that increasing social

16 | P a g e 
vulnerability will facilitate recovery' (cited in Financial Times $2011 \mathrm{a}$ ). Then, on 9 th and $11^{\text {th }}$ June protestors in Spain clashed with police, as new legislators took office before, on $19^{\text {th }}$ June 2011 , thousands of protestors - in almost a hundred events across the country - took to the streets to rally against the Pact for the Euro (Reuters $2011 \mathrm{~b}$ ). Finally, following the European Trade Union Confederation's (ETUC) protest in Brussels (29th September 2010), the Confederation staged a large protest on 21 st June 2011 in Luxembourg ahead of the ratification of the Euro Pact by European Council officials (23rd-24th June). As 2012 began, further demonstrations were associated - inter alia - with new property taxes (Ireland), pension reform (Poland) and transport privatization (Brussels).

\section{"Turning a deaf ear"}

Measuring the effects or effectiveness of the protests is however, problematic. Their rising prominence was certainly sufficient to alarm markets. From the perspective of capital, the protesters may yet have a 'significant influence on the fate of the euro and its bond markets as they could dictate how far governments go in pushing through aggressive budget cuts' (FT 2010). From another angle though, the protests - and not simply threats of financial speculation - are integral to understanding the invocation of depoliticisation by state managers. As Slavoj Zizek (2010: 86-87) has it, Europe has been entering 'a period in which a kind of economic state of emergency is becoming permanent: turning into a constant, a way of life... [bringing] with it the threat of far more savage austerity measures, cuts in benefits, diminishing health and education services and more precarious employment'. The most obvious conclusion is that the protests have resulted in little substantive change to the policy agenda that grips Europe.

Evidence to support the claim that successes have been limited abounds. In Spain for example, the indignados ("the indignant ones") were the Spanish arm of the Occupy movement, rallying against 'the greed of politicians and banks' (Indignados 2012). Despite being the most consistent and outspoken movement of 2011, they also chose nontraditional means to voice their grievances. As the crisis escalated in Spain, with unemployment reaching 4.9million (21.3 per cent) in March 2011, and a sweeping overhaul of the labour market, a raised retirement age, and extensive cuts to social spending the first protests took place in May 2011 and the movement rapidly swelled. Not linked to any specific organization it began through social networking (internet) sites, making it the first of its kind in Europe (EESC 2011). Consequently, the protestors did not target or support any particular political party or view, but expressed a rather straightforward dissatisfaction with the current state of their country. Indeed, their calls for 'real democracy' also deliberately eschewed traditional trade unions and media commentators as avenues for political activism (The Guardian $2011 \mathrm{~b}$ ). 
By the first anniversary of the movement though (May 2012), the successes of the movement were hard to gauge. On the one hand, the Spanish media continued to contend that the movement had failed, by focusing only on 'discrediting political institutions' without 'identifying clearly the alternative' (El Pais 2011). On the other hand, the movement - which had now spread from the Puerta del Sol, Madrid to the regions - was 'gaining experience in coordination and communication' (Likki 2012: 2). This kind of decentralization of the movement aided two objectives: to promote direct and participatory democracy in the local sphere; and to 'retake the public sphere' as 'the space in which citizens deliberate about their common affairs' (Sanchez 2012). On the former, 'successes' included time banks - non-monetary reciprocal service between the participants of the assembly; and the 'stop forced evictions' campaign that prevented approximately 200 forced evictions in 2011 . Whilst on the latter, the movement had arguably lost a grip on the political battle over austerity (Delclos \& Viejo 2012).

Elsewhere, similar conclusions could be drawn. Victories for the True Finns party in the April 2011 elections prompted finance minister, Social Democrat Jutta Urpilainen, to make further aid to the European bailout funds conditional on receiving collateral from Greece in return. Again though, the gains were merely formal rather than substantive, since the complex collateral model would involve Athens lending its own banks sovereign bonds, which would then be swapped and sold, the revenue from which would be invested in Triple-A (that is, better quality) bonds, which would effectively constitute the collateral Finland had demanded. In exchange though, Finland forfeited the right to pay its share of the bailout costs in five tranches, meaning it was liable for higher interest costs (Open Europe 2011).

Yet the key argument of this paper is not simply that democracy has ultimately failed; instead, faced with growing disaffection and in search of an elusive "legitimacy" - without of course surrendering to democratic demands - state managers have (re)turned to depoliticisation. Two examples will again suffice: in Italy, Italian Prime Minister Silvio Berlusconi only narrowly survived a confidence vote, prompted by his $€ 54$ bn fiscal consolidation plan and a rising number of dissidents within the PM's own People of Freedom (PdL) party (The Economist 2011). Finally, on the $8^{\text {th }}$ November 2011 the Premier failed to secure the necessary 316 majority on a budget vote, which lead to his resignation (Reuters $2011 \mathrm{c}$ ). This was followed though, by a further (successful) vote (12th November) on debt-reduction policies - in a move that was heralded by EU President van Rompuy as 'a major step in the right direction, containing the measures to put Italy back on track and, when implemented, to start regaining the necessary credibility' (van Rompuy 2011) before a new government led by Mario Monti was formed. Importantly, the incoming Monti executive garnered a high degree of popularity with EU, ECB, and IMF officials (Bloomberg 2011 ). Moreover, the former Competition Commissioner set about warning politicians that they would have to be forced to answer to the Italian public if they rejected the sweeping 
cuts that would end the debt crisis. Finally, it was also decided that a government of elected politicians was unfit for the severity of the task in hand. Monti therefore assembled a group of technocrats dominated by university academics, a bank CEO, and a naval officer; that is, ministers who were largely 'unknown to members of the Italian general public' (The Guardian $2011 \mathrm{c}$ ).

Perhaps the most insightful example though is that of the referrals to the German Federal Constitutional Court. Here a clear struggle emerged between crisis managers in parliament and government on one side, and citizens and opposed parliamentarians on the other. At stake were the new laws aimed at rescuing the euro, and the Federal Constitutional Court was responsible for adjudicating between the competing claims, as state managers deferred to the "autonomous" legal institution.

Midway through 2011 a series of constitutional complaints were lodged against the aid measures for Greece and against the euro rescue package (FCC 2011). The complaints were raised by five academics and a Bavarian lawmaker. They contended that the bailouts violated property rights and other protections in the German and European constitutions, as well as breaking the "no-bailout" clause in the European Union's treaty, which essentially states that neither the EU nor member states should take on other governments' liabilities (Reuters $2011 \mathrm{~d}$ ). The plaintiffs were not alone though; they were symptomatic of a growing German antipathy to the idea of successive bailouts to "profligate" debtor countries. Though the initial lawsuits were subsequently rejected - on the grounds that the new mechanisms did not significantly impair the budgetary autonomy of future Bundestag's - they paved the way for later attempts.

Indeed, by July 2012, the whole of Germany's socialist Left party threatened to file a motion to prevent the ratification of both the ESM and fiscal pact (Deutsche Welle 2012). For policymakers, the temporary mandate of the European Financial Stability Facility (EFSF) had been insufficient for the gravity of the ongoing financial speculation. Consequently, the (ostensibly exogenous) imperatives of financial market turbulence had led to a new and more comprehensive set of bailout financing instruments: 'crisis [had thus] forced the necessary coordination...[acting as] the midwife to...new institutional arrangements' (Rehn $2010 b)$.

Following this, on the 29th June 2012 the German Bundestag adopted the draft bill for an Act for Financial Participation in the ESM. A total of 37,000 German plaintiffs (in a group entitled "More Democracy") this time rallied in protest at the removal of safeguards of 'parliamentary freedom to decide in matters concerning the budget' which would thereby 'transfer essential duties and powers to the European Stability Mechanism in a way which is incompatible with...the principle of democracy' (BVerfG 2012 §149). On the other hand, the Federal Government contended that the complaints were unfounded, emphasising that the 'overall budgetary responsibility of the Bundestag is safeguarded' since the 
'democratic supervision of the work of the European Stability Mechanism is largely effected by way of rights of approval and participation [so that] the fundamental decisions of the European Stability Mechanism are subject to approval in the German Bundestag' (emphasis added ibid. § 182).

The decision of the Constitutional Court was illuminating. Faced with another threat to both the future of the Euro zone and, more specifically, the new Fiscal Compact and ESM strategies the German Court requested that ratification of the ESM be delayed, allowing more time to scrutinise its details (Der Spiegel 2012). German policymakers reluctantly deferred to the judgement of the Constitutional Court (Bundesregierung 2012). The prima facie conclusion was that 'constitutional democracy [was] fighting back'; wherein the 'need to manage the crisis... had clashed head on with Germany's constitutional democratic settlement' (Persson 2012). The Court's decision (12th September 2012) was however, ultimately providential: rubber stamping the new Europeanised mechanisms with a legal legitimacy, it reinforced conceptions of the "economic necessity" given threats to the very stability of the Union itself (BVerfG 2012).

The Court emphasized the importance of obtaining and maintaining Bundestag responsibility for budgetary decisions, emphasising that the ESM did not fundamentally alter the European Treaties that gave the Bundestag this role (§ 191-201). It then stated however, that no absolute upper limit on German payment obligations could be derived directly from the principle of democracy ( $\$ 200)$. This meant that it agreed to German exposure up to a limit of $€ 190 \mathrm{bn}$, as negotiated under the ESM and on which the Bundestag had - in principle - been asked to vote. Thus the Court focused primarily on reinforcing that any additional increases in German liabilities would require Bundestag approval (§ 206-244). The point, in an immediate sense, was that this inadvertent example of depoliticisation had diverted attention away from the Merkel government as architects of Europeanised adjustment mechanisms.

Yet the ESM also showed at least three other signs of reducing political discretion and democratic participation that were not examined by the Constitutional Court. Firstly, the management of the ESM was comprised of a Board of Governors, made up of member states' Finance Ministers, with little room for national or European level parliamentary participation or control (Allianz gegen den ESM 2012). Secondly, the legality of the mechanism was highly questionable. The legal base for the mechanism was article 122 of the EU Treaty, an article that was intended to provide assistance to EU states in the event of natural disasters or sudden energy blackouts (ECOFIN 2010b: 7, Open Europe 2010: 6). The ESM would function by widening the definition of emergency conditions, since ministers now argued that 'we are facing such exceptional circumstances [that] the mechanism will stay in place as long as needed to safeguard financial stability' (ECOFIN $2010 b: 2)$. Moreover, contrary to the EU Treaties which clearly specify that decisions concerning the EU budget should be taken by unanimity, this decision was taken by 20 I P a g e 
majority vote. In other words, no individual member state would have been able to veto this highly controversial package (see Open Europe 2010: 7). Thirdly and finally though, the decision on which countries would qualify for loans under the ESM would be made by Qualified Majority Voting (QMV), meaning that no individual member state would hold veto powers. This was an important change from the earlier EFSF package. Indeed, the 'exceptional circumstances' appeared to have worsened, providing the rationale for a further reduction in democratic scrutiny and participation (European Council 2011: 6).

The case brought before the German Federal Constitutional Court had, understandably, focused only on a specific question of budgetary authority under the new mechanisms. The pro-European ruling of the Court had nonetheless indirectly confirmed the legitimacy - at least in legal-technica/terms - of the strategies. It constituted an example of ad hoc depoliticised statecraft, whereby the same "imperatives" that had shaped state managers' decisions were refracted through other politico-legal institutions as they also framed the Court's decisions. These "imperatives" - ostensibly related to placating nervous financial markets - in fact reflected the tightening of market discipline over labour and money, and the reconfiguration of class relations. This meant that state managers had sought to establish depoliticised, Europeanised mechanisms and that, albeit indirectly, features of domestic democratic apparatuses had reinforced rather than rejected these strategies. The paradox that democratic institutions are responsible for giving birth to non-democratic apparatuses is more easily comprehended in light of the argument that the state - rather than being a neutral instance - is itself an agent in the reproduction of capitalist accumulation. Whether or not this depoliticisation will ultimately secure the requisite legitimacy in the eyes of the dependent masses however, is the question to which I turn in the conclusion.

\section{CONCLUSION}

This paper has argued that there are strong reasons to believe that greater democratic participation will not be the strategy pursued by domestic and European-level state managers to secure the legitimacy of the newly Europeanised mechanisms of adjustment. In fact, the rising protests at the domestic level have, I suggest, been an important factor precipitating the depoliticisation of policymaking at the European level. This means that the crisis of coherence - or the formulation of a coherent political approach - is but one challenge confronting state managers. The other is a "legitimacy crisis", in part also derived from the institutional stickiness of struggles between the liberal and the democratic functions of the state (see Habermas 1988[1973]). I have argued that depoliticisation has been the strategy pursued in response to both coherence and legitimacy crises. Or as Jurgen Habermas has it, state managers have sought to 'replace the executive federalism implied in the Lisbon Treaty with an intergovernmental 
domination of the European Council...a regime that would allow for the projection of market imperatives onto national budgets without any specific democratic legitimation' (2011).

At the time of writing then, the capacity for depoliticisation to successfully manage the legitimacy crisis is an open-ended question. In closing, and following lan Bruff (2012), I would argue that the success or failure of three skeins of this depoliticisation will ultimately prove decisive: the first is the success (or otherwise) of state appeals to its own incapacity, invoking insurmountable, exogenous imperatives for liberal reform; the second is a longer term 'recalibration of of what kind of activity is feasible and appropriate for 'non-market' institutions to engage in' (ibid.: 114); and the third is the gradual acceptance of the state as non-democratic through its deferral to technical-legal process.

This amounts to an attempted reconfiguration of the form - though not the function - of the state itself. The debt and democracy crises are acting as midwife to the latest stage in depoliticized statecraft. State managers are less interested in concession seeking, or neutralizing class antagonisms through credit expansion, preferring instead the exclusion of particular disaffected social groups and a more coercive means of enforcing market discipline. The depoliticized responses outlined above are signs that state managers are increasingly "turning a deaf ear" to democratic demands, though this is implicit in the claim that sustaining a liberal, competitive economy is dependent on strong state authority (Bonefeld 2010). In essence then, Simms' proposals for reform will have to be assessed against the background of the manner in which the crisis of the European political economy will develop - that is, from debt to political crisis and social unrest - and the challenge this has posed to the market liberal framework of the EU.

\footnotetext{
' For a more extensive account see (Dyson \& Quaglia 2010).

ii Gros and Thygensen had noted for example, the concerns of German Chancellor Schmidt over compromises between the Italian ruling class and the communist party (Daniel Gros and Niels Thygensen, European Monetary Integration, London: Longman, 1992, p. 35).

iii Figures calculated from European Central Bank data (ECB 2006: 67).

iv That is, countries that qualified for structural support from EU funds so as to speed up their convergence to EU per capita income levels.

$\checkmark$ This involved increasing the effectiveness of the public administration, stepping up pension and healthcare reform, improving labour market functioning and the effectiveness of the wage bargaining system, enhancing product market functioning and the business environment, and maintaining banking and financial sector stability.
} 
vi I am grateful to Paul Cammack for highlighting this point.

vii It should also be noted that the Commission had made the case for deeper and broader economic coordination repeatedly through this period, including at the 2009 Annual Statement on the Euro Area, and the 2008 Communication on EMU@10.

\section{REFERENCES}

Allianz gegen den ESM (2012) ,Das sind die fünf Hauptprobleme des ESM“, organisation website.

Almunia, Joaquín (2009) Beyond the crisis: what strategies for a sustainable economy?, speech at Brussels Economic Forum, 'Beyond the Crisis: A Changing Economic Landscape', Brussels, 14 May 2009.

Andersen, Svein \& Tom Burns (1996) 'The European Union and the Erosion of Parliamentary Democracy: A Study of Post-Parliamentary Governance', Svein S. Andersen and Kjell A. Eliassen (eds) The European Union: How Democratic Is It? London: Sage.

Anderson, P. (1997) 'The Europe to Come', in Gowan, P. and P.Anderson (eds) The Question of Europe, London: Verso.

Best, Jacqueline (2005) The Limits of Transparency: ambiguity and the history of international finance, Ithaca: Cornell.

Bieler, Andreas (2006) The Struggle for a Social Europe: trade unions and EMU in a time of global restructuring. Manchester: Manchester University Press.

Bloomberg (2011) 'Italy Chamber to Hold Vote Paving Way for Berlusconi Exit', 12th November 2011.

Böhm, F. (1937). Ordnung der Wirtschaft. Berlin: Kohlhammer..

Bonefeld, Werner (1998) 'Politics of European Monetary Union: Class, Ideology and Critique', Economic and Political Weekly, 33(35). 
Bonefeld, Werner (2002) 'European integration: the market, the political and class', Capital and Class 26: 117-142.

Bonefeld, Werner (2005) 'Europe, the Market and the Transformation of Democracy', Journal of Contemporary European Studies 13, 1.

Bonefeld, Werner (2010) 'Free Economy and the Strong State', Capital and Class, vol. 34 no. 1.

Brittan, Samuel (1976): 'The Economic Contradictions of Democracy' in A King (ed), Why is Britain Becoming Harder to Govern? London: BBC.

Bruff, Ian (2012) 'Authoritarian Neoliberalism, the Occupy Movements, and IPE', Journal of Critical Globalization Studies 5.

Bundesregierung (2012) 'The way is free for the ESM and the Fiscal Pact', $12^{\text {th }}$ September 2012 , Berlin.

Burnham, Peter (2001) 'New Labour and the politics of depoliticisation', British Journal of Politics and International Relations, 3, 2.

BVerfG (2012) Extracts from the decision of the Federal Constitutional Court of 12 September 2012,

Commission (2006a) Time to Move Up A Gear, January 2006 Annual Progress Report on Growth and Jobs, Brussels: European Commission.

Commission (2006b) European Economy: economic forecast no. 5, 2006, Brussels:

Commission,

Commission (2006c) Implementing the Renewed Lisbon Strategy for Growth and Jobs: a year of delivery, Communication to the European Council, 12 December 2006, Brussels, Commission. 
Commission(2008) EMU@10: Successes and challenges after ten years of Economic and Monetary Union, Brussels: Commission.

Commission (2009a) Commission assesses Stability and Convergence Programmes of Bulgaria, the Czech Republic, Denmark, Germany, Estonia, Hungary, the Netherlands, Poland, Sweden, Finland and the United Kingdom, 18 February 2009, Brussels:

Commission.

Commission (2009b) Communication for the Spring European Council: Driving European Recovery, Brussels, 4 March 2009, Brussels: Commission.

Commission (2009c) Economic Crisis in Europe: Causes, Consequences and Responses, European Economy 7, Brussels: Commission.

Commission (2009d) Communication from the Commission to the European Parliament and the Council: Long-term sustainability of public finances for a recovering economy, Brussels, 14 October 2009. Brussels: Commission.

Commission (2010a) Press Release: Commission assesses Stability Programme of Greece, 2010, 3 February 2010. Brussels: Commission.

Commission (2010b) Commission assesses Stability Programme of Greece; makes recommendations to correct the excessive budget deficit, improve competitiveness through structural reforms and provide reliable statistics, Brussels, 3 February 2010. Brussels: Commission.

Commission (2010c) Reinforcing economic policy coordination, Communication from the European Commission to the European Parliament, the European Council, the Council, the European Central Bank, The Economic and Social Committee, and the Committee of the Regions, 12 May 2010. Brussels: Commission.

Commission (2010d) Economic Forecast, Autumn 2010, Brussels: European Commission. 
Darvas, Zsolt, Jean Pisani-Ferry and André Sapir (2011) A comprehensive approach to the Euro-area debt crisis, Bruegel Policy Brief, 2011.

Delclos, Carlos and Raimundo Viejo (2012) 'The day after: the movement beyond the protest', 14th January 2012, RoarMag.org.

Der Spiegel (2010) Protests in Europe Ahead of Euro Summit, 15th December 2010.

Der Spiegel (2011) Bailout fatigue forces Germany to hear the sceptics, 11 January 2011.

Der Spiegel (2012a) Germany Faces Delay in Ratifying Euro Rescue Fund, 21 st June 2012.

Deutsche Welle (2012) 'German government, opposition join forces to save euro', European Community (EC) (2009) Memorandum of Understanding between the European Community and the Republic of Latvia, 28 January 2009.

Dyson, Kenneth \& Lucia Quaglia (2010) European Economic Governance and Policies. Volume II: commentary on key policy documents, Oxford: Oxford University Press.

ECB (2006) Annual Report, ECB: Frankfurt.

ECB (2008) Financial Stability Review 2008, ECB: Frankfurt.

ECB (2010) Monthly Bulletin, June 2010. ECB: Frankfurt

ECOFIN (2008) Council Conclusions on a coordinated EU response to the economic slowdown, 2894th ECONOMIC and FINANCIAL AFFAIRS, Luxembourg, 7 October 2008.

ECOFIN (2009a) Council Conclusions, 2967th Meeting, Luxembourg, 20 October 2009, p. 6.

ECOFIN (2009b) Council Conclusions, 2972nd Meeting, Luxembourg, 10 November 2009.

ECOFIN (2010a) Council Conclusions, 2994th Meeting, Brussels, 16 February 2010. 
ECOFIN (2010b) Press release: extraordinary meeting, ECOFIN, Council of the European Union, $9^{\text {th }} / 10^{\text {th }}$ May 2010.

The Economist (2011) 'Europe's most earnest protesters', 14th July 2011.

EESC (2011) 'Los Indignados', European Economic and Social Committee blog, 26th May 2011.

El Pais (2011) 'Indignados en la calle', 17th May 2011

Emerson, Michael et a/ (1992): 'One Market, One Money', Oxford University Press, Oxford European Council (2006) Presidency Conclusions, 23-24 March 2006, Brussels, Council of the European Union.

ETUC (2010) Euro-demonstration: No to Austerity - priority for jobs and growth!, ETUC website.

European Council (2010) Statement by the Heads of State and Government of the Euro Area, Brussels, 25 March 2010

European Council (2011a) Conclusions, Brussels, 24-25 March 2011.

European Council (201 1 b) Statement by the Euro Area Heads of State or Government, Brussels, 9 December 2011.

Eurogroup and ECOFIN (2011) Statement by the Eurogroup and ECOFIN Ministers on Portugal, Brussels, 8 April 2011.

Euro Area Heads of State and Government (2008) Declaration of a Concerted European Action Plan of the Euro Area Countries, 12 October 2008, Brussels.

Euro Area Heads of State and Government (2011) Conclusions, Brussels, 11 March 2011.

FCC (2011) 'Constitutional complaints lodged against aid measures for Greece and against 
the euro rescue package unsuccessful - - no violation of the Bundestag's budget autonomy' Press release, Federal Constitutional Court, 7th September 2011.

Financial Times (2010) 'Austerity pros and cons preoccupy markets', 28 th June 2010.

Financial Times (2011a) Spain protesters turn anger against Brussels, 19 June 2011.

Financial Times (2011b) French union warns of discontent at 'Euro pact', 19 April 2011.

Follesdal, Andreas and Simon Hix (2006) 'Why There is a Democratic Deficit in the EU: A Response to Majone and Moravcsik', Journal of Common Market Studies 44, 3.

Gill, Stephen (1998) 'European Governance \& New Constitutionalism: EMU \& alternatives to disciplinary neo-liberalism in Europe.' New Political Economy. Vol. 3: 1 (1998) 5-26.

Gros, Daniel \& Niels Thygesen (1992) European Monetary Integration, Longman: Harlow.

The Guardian (2010) 'Ireland bailout protest draws 100,000 to Dublin streets', 27th November 2010.

The Guardian (2011a) ‘Angela Merkel: Europe's saviour - or biggest problem?', 22nd November 2011.

The Guardian (2011b) 'How corruption, cuts and despair drove Spain's protesters on to the streets', 21 st May 2011.

The Guardian (2011c) ‘Eurozone crisis: New Italian government announced', 16 th November 2011.

Habermas, Jurgen (1988[1973]) Legitimation Crisis, Cambridge: Polity.

Habermas, Jurgen (2011) 'Democracy is at stake', Le Monde, 27 April 2011 , Paris 
Hamilton, Adrian (2011) 'The real euro crisis is yet to explode', The Independent, 18th August 2011.

Hay, Colin \& Daniel Wincott (2012) The Political Economy of European Welfare Capitalism, Palgrave, Basingstoke.

Hayek, Friedrich (1949) Individualism and Economic Order, Routledge and Kegan Paul, London.

Heipertz, Martin and Amy Verdun (2010) Ruling Europe: The Politics of the Stability and Growth Pact, Cambridge: Cambridge University Press.

IMF (2006) Article IV Consultation - Staff Reports, various countries, 2006, Washington DC, IMF.

Indignados (2012) The "Indignados" Occupy Together website.

http://www.theindignados.org/

Jessop, Bob (2012) 'A Cultural Political Economy of Financial Crisis: Money Forms, Crisis Displacement, and Deficit Hysteria', paper presented at the Northern IPE Network, University of Lancaster, 17th February 2012.

Kok Report (2004) Facing the Challenge: the Lisbon strategy for growth and employment, Report from the High Level Group chaired by Wim Kok, 2004, Luxembourg, Office for Official Publications of the European Communities

Likki, Tiina (2012) 15M Revisited: A Diverse Movement, United for Change, Alternative Foundation Study.

Macartney, Huw (2009) Disagreeing to Agree: Financial Crisis Management within the 'Logic of No Alternative', Politics 29(2): 111-120 
Macartney, Huw (2011) "Crisis for the State or Crisis of the State?" The Political Quarterly 38, no. 2(2011) : 193-203

Marks, Gary et al. (2002) 'National Political Parties and European Integration'. American Journal of Political Science, 46, 3, 2002, pp. 585-94.

Marx, K. (1990 [1 867]), Capital: A Critique of Political Economy (vol. 1), London: Penguin.

Moss, B. (2000)'The European Community as Monetarist Construction', Journal of European Area Studies, 8(2)

Müller-Armack, A. (1947) Wirschaftslenkung und Marktwirtschaft, Verlag für Wirtschaft und Sozialpolitik, Hamburg.

OECD (2006) Economic Policy Reforms: Going for Growth, Paris, OECD,

O'Grady, Sean (2010) 'Greece leads Europe's winter of discontent', The Independent, 24th February 2010.

Ollman, Bertell (1998) 'Why Dialectics? Why Now?', Science and Society 62(3): 338-357.

Open Europe (2010) The rise of the EU's economic government: Proposals on the table and what has already been achieved, June 2010.

Open Europe (2011) Collateral Damage, OpenEurope blog, 19th August 2011.

Padoa-Schioppa, T. (1994) The Road to Monetary Union (Oxford: Clarendon Press).

Parliament (2010) Speech by George Papandreou, 'Time to end opportunistic speculation', European Parliament Economic and Monetary Affairs Committee, 18 March 2010.

Persson, Mats (2012) Personal Interview with Mats Persson, Director of Open Europe Research Centre. 
Radice, Hugo (2011) 'Cutting government deficits: economic science or class war?', Capital \& Class, 35,1, pp. 125-37.

Raunio, Tapio (1999) 'Always one step behind? National legislatures and the European Union', Government and Opposition 34(2): 180-202.

Rehn, Olli (2010a) European Commissioner for Economic and Monetary Policy, Reinforcing economic governance in Europe, European Policy Centre Brussels, 15 April 2010

Rehn, Olli (2010b) 'What is needed from European Policy Makers Now? Building Europe's Economic Future' - EEGM Policy Dialogue Brussels, 1 December 2010.

Reuters, (2009) 'Greek/German bond yield spread rewidens', 14 December 2009.

Reuters (2011a) Euro zone closer to new anti-crisis package, 2 February 2011.

Reuters (2011b) Tens of thousands march against Euro Pact in Spain, 19 June 2011.

Reuters (2011c) 'Berlusconi to resign after parliamentary setback', 8th November 2011.

Reuters (2011d) 'Germany's top court to rule on euro bailouts September 7', 23rd August 2011.

Rhodes, Rod (1994) 'The hollowing out of the state: the changing nature of the public service in Britain', The Political Quarterly, 65, 2, pp. 138-151.

Röpke, W. (1942). International Economic Disintegration. London: Hodge.

Röpke, W. (2009). The Social Crisis of Our Time. New Brunswick: Transaction..

Sanchez, Marta (2012) 'Losing strength? An alternative vision of Spain's indignados', RoarMag.org. 
Schelkle, Waltraud (2010) Government responses to the economic crisis in the Euro area: a battle of the sexes between Marianne and Michel?, paper presented at the University of Princeton, $13^{\text {th }}$ October 2010.

Schmidt, Vivien (2012) Democratizing the Eurozone, Social Europe Journal, $15^{\text {th }}$ May 2012.

Shields, Stuart (2008) 'How the East was won: transnational social forces and the neoliberalisation of Poland's post-communist transition', Global Society 22(4): 445-468

Simms, Brendan (2012) 'Towards a mighty union: how to create a democratic European superpower', International Affairs 88, 1, pp. 49-62.

The Telegraph (2010) Greece's 'worst fears' confirmed, says PM George Papandreou, 26th February 2010.

van Rompuy, Herman (2010) President of the European Council, following the last meeting of the Task force on economic governance, Luxembourg, 18 October 2010.

Van Rompuy, Herman (2011) "The economic and political challenges for Europe", Speech by President Herman Van Rompuy at the opening of the Academic Year 2011-2012, European University Institute.

Zizek, Slavoj (2010) ‘A Permanent Economic Emergency', New Left Review 64. 